\section{UK research grants suffer from SERC's lack of money}

\section{London}

FIGURES published this week in the Science and Engineering Research Council's corporate plan highlight the growing imbalance in supply and demand for UK research grants. Expenditure has increased slightly since the first plan was published in 1984-85, but costs have increased further and the council cannot support the increasing number of grant applications. The research grant success rate for alpharated proposals decreased from 72 per cent to 48 per cent in science and from 98 per cent to 86 per cent in engineering. For standard grants, the success rate decreased from 28 per cent to 20 per cent in science and 39 per cent to 32 per cent in engineering. The council hopes to increase the percentage of grant-in-aid spent on research grants from 33 per cent in 198788 to 40 per cent, and to maintain at a constant level the numbers of research assistants supported by its grants.

Expenditure on equipment must increase, and the council hopes to achieve this by increasing the proportion of grant money that supports equipment and by allocating for equipment money for the interdisciplinary research centres (IRCs). Five IRCs have been established and the council plans for another 17 by 1991 . More than 300 applications to host the centres have been received. But the plans for expansion depend on the money available. Only 50 per cent of the cost can be met from existing funds, says the council. It will seek further money from the research council's flexibility fund and from the Department of Education and Science.

The council plans to continue increasing the proportion of its budget devoted to strategic research with the aim of achieving a 60:40 ratio between support for strategic and for basic research by $1990-91$. In the past decade, support for strategic research has increased from 42 per cent of total expenditure in 1978-79 to 54 per cent in 1987-88. For basic research, the council would like to make the support mechanism more long-term and to link expenditure to the country's gross domestic product.

Other council plans include an increase in expenditure on the LINK programmes, which are supported jointly by the research councils, government departments and industry. It plans to initiate eight more programmes annually over the next three years and to increase annual expenditure to $£ 20$ million in five years.

The council is also planning a collaborative programme of atmospheric research with the Natural Environment Research Council, to integrate satellite, ocean, Earth and atmosphere measurements with gas-reaction kinetic data and with related computer simulations.

Expenditure on space science will not be increased and, so that it might in future select parts of the science programme of the European Space agency in which to get involved, the council urges a review of ESA's method of operation to include some optional elements.

Christine McGourty

\title{
Soviet bloc research criticized
}

\section{London}

Comecon's Comprehensive Programme of Scientific and Technological Cooperation, the first major policy development of the Gorbachev era, has been roundly criticized on Prague radio. Comecon, the trade and development alliance of the Soviet bloc, is celebrating its fortieth anniversary this week.

The programme was intended, when launched in December 1985, to encourage joint enterprises between member countries and was regarded as a step towards decentralization. Previous policy had been heavily orientated towards the Soviet Union, with a Soviet "head" institute for every project. The best-known exception had been the low-temperature magnetism laboratory at Wroclaw in Poland.

Radio Prague commentator Vladimir Vercak now says that within a few months of the adoption of the new programme, it was clear that differences of economic management in member countries would prevent the goals of the programme being attained. Joint enterprises have been successfully established only where longstanding partnerships already existed, but the lack of an intra-bloc currency is also an impediment. Unless the economic conditions of member states are rapidly improved, he concludes, the programme will not realize "Comecon's scientific and technological potential".

A NATO conference last autumn showed that there may be other problems. Speakers with first-hand knowledge of bloc countries drew attention to the way that the lack of equipment and resources tempts scientists and engineers to seek collaboration outside the bloc, while enterprises are often more interested in preserving their chances in world markets than in the needs of its socialist partners.

Vera Rich

\section{Most French pupils to go to university}

Paris

A major overhaul of the French education system published last week by Education Minister Lionel Jospin aims to make France the best-educated nation in Europe by the year 2000 . The plans, estimated to cost between $\$ 8,000$ million and $\$ 160,000$ million, include massive recruitment of teachers, better teacher training and a revised curriculum. The goal is that 80 per cent of school-leavers should be able to go to university, while the rest should not leave school without a diploma in business or industrial skills.

Education and research were priorities in President François Mitterrand's preelectoral "letter to the nation" last spring. Despite a national curriculum, with 90 per cent of pupils attending state schools, only 40 per cent get the chance of a university education. Every year, 100,000 pupils leave school without any qualifications. Over one third of school leavers who do obtain their ' $b a c$ ' (university entrance certificate) and go on to university fail to complete their course, many dropping out after the first year having failed the stiff examinations.

Jospin says that schools have an unwritten contract with children and their parents to provide the education they desire. One necessary step needed to fulfil this contract is to reduce class sizes. To this end, $\mathbf{3 0 0 , 0 0 0}$ new teachers are to be recruited over the next ten years. To make the profession more attractive, money will be provided to close the gap between the university-oriented 'lycées', and the less specialized, but also lower status, 'colleges', which are understaffed and have a high failure rate at the baccalaureat. Teacher-training institutes are to be set up and secondments introduced to allow teachers to improve their career prospects, as well as to catch up in their subjects.

The two main concerns with Jospin's plans are that success rates will be made artificially high by lowering pass marks, and that already overcrowded and crumbling universities could not cope with a large influx of students. Despite these objections, and some resistance from lycée teachers, the reforms have met with general approval.

Peter Coles

\section{Correction}

The-high field test apparatus SULTAN at the Paul Scherrer Institute (see photograph in Nature 336, 338; 1988) consists of magnetic spools contributed by ENEA and ECN. The design of the facility and the cryogenic infrastructure was realized by the Paul Scherrer Institute. Euratom helped to finance both construction and running costs of the apparatus. 